Western University

Scholarship@Western

$4-2020$

\title{
How Do Leaders Judge What is a Responsible Course of Action?
}

Rita A. Gardiner Ph.D

The University of Western Ontario, rgardin2@uwo.ca

Follow this and additional works at: https://ir.lib.uwo.ca/edupub

Part of the Education Commons, and the Leadership Studies Commons

\section{Citation of this paper:}

Gardiner, R. (April, 2020). How do leaders judge what is a responsible course of action? (pp. 125-138). In Ladkin, D., (Ed.), Rethinking leadership, 2nd edition. Cheltenham, UK \& Northampton, MA: Edward Elgar. 


\section{How do leaders judge what is a responsible course of action?}

In this chapter, I ask two interrelated questions. First, how do leaders judge what is a responsible course of action? Second, and relatedly, how do others judge what constitutes responsibility in leadership action? The core argument I put forward is that thinking with Hannah Arendt deepens our comprehension of what it might mean to lead responsibly. She encourages us to recognize that leading in a responsible manner is, above all, a judgment call. From an Arendtian perspective, to judge responsibly entails taking the time to reflect upon a decision so as to weigh up the different sides of an argument. Thus, a measured response requires a willingness to approach an issue from multiple perspectives, and to engage in the kind of reflective thinking that Donna Ladkin (2010) argues is critical to leadership.

Yet what happens when a leader's judgment goes awry? To address this question, I examine a political scandal that has shaken many Canadians' faith in their current Prime Minister, Justin Trudeau. He came into office pledging that his government would do politics differently, and be more transparent in its decision-making. But an allegation of political interference suggests Trudeau is practicing what cynics might call politics as usual. If these allegations of political interference are true, then his actions indicate not only a lack of responsibility, but also a profound lack of judgment.

What I find noteworthy about this political example is that it is not straightforward as to what the Prime Minister's primary responsibility is. Although it may appear easy to determine when a leader is acting responsibly, there are times when such determination is not clear-cut. As with any thorny problem, there are numerable issues a leader must take into account as they decide the best course of action. This requires leaders to judge carefully. In the frenetic times in which we live, however, it is hard for a leader to take the time to examine an issue from diverse 
perspectives. When leaders live in constant distraction, they may lose the habit of reflective thinking, thus making it difficult to make measured decisions. One way of dealing with this problem is that leaders turn to trusted advisers for assistance. But what happens, as in this case, when those advisers are at odds? How then does a leader act in a responsible way, judging which advice to take? In addressing these questions, I plan to put Arendt's thinking about responsibility and judgment to the test.

This chapter unfolds as follows. I begin by outlining Arendt's approach to phenomenology. Next, I turn to her exploration of collective and individual responsibility. Examining these different facets of responsibility illustrates how we sometimes confuse individual responsibility with obedience to a leader or a law. Such obedience is problematic, in her view, since it can lead to a lack of personal responsibility. Next, I turn to her account of judgment. For Arendt, our particular standpoint, or being-in-the-world, will influence not only how we judge what is responsible in others, but also what we perceive as responsible action for ourselves. Following this, I turn to politics, and examine the political scandal outlined earlier. In the discussion and conclusion section, I examine what this case tells us about the complexity of leading responsibly. Such complexity is necessary to consider, as scholars continue to build upon the nascent theory of responsible leadership (Maak \& Pless, 2006).

\section{Arendt and phenomenology}

In a comment to a student, Arendt stated "I am a sort of phenomenologist...but not in Hegel's way or Husserl's" (Young-Bruel, 1992, p. 405). Arendt has a novel approach to phenomenological inquiry that has been subject to scholarly contestation (Movlje, 2019). One reason for this contestation is because Arendt's influences are many, including the hermeneutic phenomenology of Martin Heidegger, and the existential humanism of Karl Jaspers. Another 
important influence was her close friend and comrade, the essayist Walter Benjamin (Benhabib, 2010). Adopting his method of looking to the forgotten fragments of history, Arendt seeks to unearth narratives from the past that had been erased. Unearthing these forgotten narratives offers insights into the human condition. Because stories are told from multiple perspectives, Arendt argues, narratives help us understand specific phenomenon in rich and meaningful ways. Lastly, and especially pertinent to this discussion, is the depth of understanding gained from her "beloved" Kant, whom Arendt began reading at the age of 14. In particular, she regarded his approach to judgment as exemplary, because of its intersubjective basis. From an Arendtian perspective then it is through a diversity of viewpoints that we can comprehend a phenomenon in a fulsome way.

An essential component of Arendt's phenomenological approach is to understand, and interpret, specific political phenomenon. She investigates how particular political phenomenon appear in different socio-cultural and historical circumstances (Young-Bruel, 1992). I will show later how Arendt seeks to explore leadership in a relational way, highlighting the importance of a collective notion of leading, rather than a fixation on the leader. Further, Arendt's phenomenological insights into the human condition are remarkable not only for their depth of understanding, but also for their applicability to our time. As an instance, we need only look to the massive increase in sales of her book, The Origins of Totalitarianism, following the election of Donald Trump, to see the relevance of Arendt's writing to current political events. As such, her work is of note not only to political philosophy and phenomenological inquiry, but also to leadership studies (Gardiner, 2015).

An Arendtian approach requires the scholar to be "an engaged spectator, someone who lets herself be addressed by what she investigates" (Borren, 2010, p. 16). In taking up the role of 
engaged spectator, my aim is to show how an Arendtian inquiry focussing on responsibility and judgment offer insight into a particular political scandal. Such insight helps us understand what it might mean to lead responsibly. First, however, I explore Arendt's ideas about responsibility and judgment, beginning with the former.

\section{An Arendtian turn to responsibility}

Responsibility is a key term in many of Arendt's works. In The Human Condition, for example, she focuses on responsibility as it relates to action within the political sphere. In later work, such as The Life of the Mind, her perspective shifts to perceiving judgment as the "missing link" between thinking and willing (Beiner, 1992; Herzog, 2012). This perspectival shift is important to understanding Arendt's analysis of not only what it might mean to act responsibly, but also how judgment is a key component of understanding responsible action.

One reason for this shift was a result of Arendt's experience covering the trial of Adolf Eichmann. She (1963) connected his criminal deeds to thoughtlessness, and an inability to think from the perspective of others. This inability to think resulted, she argued, in Eichmann's complete lack of judgment. In her assessment of Eichmann, Arendt was attacked not only by her enemies, but also by many friends. Despite this negative reaction, she was adamant that the thoughtlessness Nazis like Eichmann showed was a result of their lack of willingness to judge for themselves, as well as their insistence they were obeying the Fuhrer's orders. But obeying orders, according to Arendt, can never abrogate a person's responsibility for their actions.

Obedience, Arendt (2003a) tells us, has a long history in political philosophy, popular since Plato and Aristotle, that "every body politic is constituted of rulers and ruled, and that the former give commands and the latter obey orders" (p. 47), Arendt disagreed, arguing this way of thinking covers over the foundational relationship between leader and led, which was not about 
obedience, but rather about offering support. Without others' support, Arendt maintains, no leader could accomplish anything of significance. From an Arendtian perspective, obedience is irresponsible, since it negates personal autonomy. And such autonomy of thought and deed is, for Arendt (1958), fundamental to a flourishing political realm.

From an Arendtian perspective, then, individual responsibility is not just about some kind of accountability to the leader, or one's friends and family, but about a responsiveness to the needs of all others. This responsiveness has similarities with Levinas' approach to responsibility (Gardiner, 2018). But what makes Arendt's approach distinct is her collective concern for others. As such, Arendtian responsibility is not centered on the self/other relationship, but on a deeper, more humane, responsiveness to diverse others. For such responsiveness we need to develop a more relational way of responding to others that is not only accountable, but also ethical.

Arendt was concerned with how a government's unethical conduct could lead to a dulling of conscience. In turn, this could negate a citizen's sense of personal responsibility (Diprose, 2008). Governmental wrongdoing can lead to a moral collapse on the part of ordinary citizenry. Such a moral collapse results when people stop thinking about their broader responsibilities to the community. These kinds of moral lapses can occur not only from acts of evil, but can also emerge from expressions of indifference. This indifference occurs when people choose to go along with others, rather than taking their own ethical stance. For Arendt, when we refuse to judge for ourselves, we fail in our collective responsibility to ensure others' well-being. Because we are all members of a community, "no moral, individual and personal, standards of conduct will ever be able to excuse us from collective responsibility" (Arendt, 2003a, p. 157).

Furthermore, she maintains that this ability and willingness to judge for oneself is not only indicative of responsibility, but also an individual quality often lacking in modern society. 
That is, for the most part we acquiesce to societal rules, rather than thinking for ourselves. Although we cannot live our lives reflecting upon everything we do, too often people prefer to go along, rather than commit to any position. And this refusal to judge is, in her view, indicative of a lack of our ethical responsibility.

Arendt distinguishes between a person's individual moral and legal responsibilities, and their political responsibilities. As she notes: "In the center of moral considerations of human conduct stands the self; in the center of political considerations stands the world" (p. 153). Because we are part of a political community, Arendt argues, it is our collective responsibility to pay attention to social injustice. Thus, if we wish to act responsibly, we must consider how our actions may affect others. Yet such consideration is complicated because, as Arendt (1958) maintains, we can never know the final outcome of a specific action. To assuage the problem of action's contingency, she maintains that promising and forgiving are important aspects of our ethical conduct. Simply put, our responsibilities to others include keeping our promises and forgiving others whenever they act inappropriately (Arendt, 1958). Such a willingness to keep one's promises and seek forgiveness are not always found in politics. Before I examine the political scandal mentioned earlier, I want to explore Arendt's notion of judgment, and its connection with responsible action and leadership.

\section{Arendt and judgment}

The concept of judgment was central to Arendtian thought. It was, according to her students and friends, the topic on which she felt most at home. There is, thus, a poignancy with regard to the fact that she died of a heart attack before completing the third part of The Life of the Mind. All we have of the final chapter is the first word she typed; "judgment." However, she 
(1992; 2003a; 2003b) discusses judgment in other writings. These writings help us understand the centrality of judgment to Arendt's thought.

Arendt turns to Kant's notion of good taste, originally an aesthetic theory, as the foundation for judgment. She regards Kantian judgment as exemplary because of its intersubjective nature. Through the act of judging, Arendt maintains, a person can take not only their own perspective into account, as they do in solitary reflection, but also consider the viewpoints of others. Through the act of judging one must attempt to come to a potential agreement with others who may not agree with one's position, but with whom one needs to fashion some kind of concord. This, I would argue, is a key facet of leadership. Besides, being willing to disagree with others is critical if one intends to take a principled stance. In times of crisis, Arendt contends, there is often no moral rulebook to follow because the situation is novel. At these times, it is neither heroes nor saints that are required, but people willing to take a moral stance by judging the situation for themselves.

In her discussion of judgment, Arendt (1992) also builds upon Kantian ideas about the role of the spectator. Unlike the actor whose deeds and words are focussed on action, the spectator is able to observe an issue from multiple perspectives. As a result of this broader perspective, Arendt contends the spectator is able to judge a situation more robustly. Consequently, it is through judgment that we come to greater understanding. Such understanding will depend upon situational context, and our specific being-in-the-world. That is, our diverse experiences in the world, and social location, will influence how we judge a particular situation.

Arendt does not provide us with a template as to what a good judgment might look like, since this would contradict her belief that each situation call for a specific response. However, 
she does argue that we can enrich our ability to judge by a willingness to take the time to comprehend diverse viewpoints before arriving at a decision. As she (1961) states:

The more people's standpoints I have present in my mind while I am pondering a given issue, and the better I can imagine how I would feel and think if I were in their place, the stronger will be my capacity for representative thinking and the more valid my final conclusions (p. 241).

By taking the time to reflect on diverse viewpoints, we can not only decide on the best course of action, but also enrich our overall understanding.

In summary, judgment and responsibility are interconnected aspects in Arendt's thought. What an Arendtian analysis helps us understand is how a refusal to judge not only influences our ability to think critically, but it also has a negative effect on individual responsibility. Her view of judgment is connected not only with the private realm, but also with the public realm of politics whereby people are willing to not only share their individual perspective, but are also willing to listen to those with whom who disagree. A willingness to engage with others is critical to the well-being of society. From Arendt's perspective, this plurality of discourse is fundamental to the flourishing of politics, to which I now turn.

\section{Leadership and politics}

Politics, in an Arendtian sense, is not about the drafting of policies, nor the achievement of particular goals. Rather, as Vasterling (2010) notes, the political is the space whereby plurality and freedom are realized through action, which, for Arendt, refers to the ability for people to speak and act freely. Thus, in its ideal state, politics represents "a form of being together where no one rules and no one obeys" (Arendt, 1992, p. 141). Too much focus on the individual leader, she (1958) contends, is detrimental to the public realm since, rather than encouraging diverse 
perspectives, it enables leaders to gain power over others. When the latter occurs then, in Arendt's view, we do not have leadership emerging, but mastery. Leadership-as-mastery can be devastating to the political environment, because it serves to restrict dialogue and debate. For Arendt (1958), leadership works best when we regard the leader not as separate from others, but as primus inter pares, first among equals. Seeing the leader as first among equals encourages people to support, rather than obey the leader.

For an Arendtian style of politics to flourish, political leaders need to encourage a plural space whereby diverse viewpoints can be expressed and examined. In the following example, I examine what happens when one leader's judgment goes awry. From an Arendtian perspective, such judgment will necessitate examining an issue from diverse perspectives before deciding on a course of action. Although what constitutes good judgment is not something that we can decide ahead of time, nevertheless, one can suggest that it requires the leader to step back from the immediate situation so as to analyze the issue from diverse perspectives, something that does not seem to have occurred in the following example.

Actor \# 1: Justin Trudeau, Canada's Prime Minister. The son of Pierre Trudeau, a former Canadian Prime Minister, Justin Trudeau has expended a lot of effort trying to justify that he is more than his father's son. When he decided to enter politics, for example, rather than seeking a safe seat in a predominantly English riding in Montreal, Trudeau ran in a workingclass French-speaking riding where neither his name nor his personal wealth were positive attributes. He won that seat easily, and, in 2014, Trudeau went on to win the Liberal leadership race, and shortly thereafter, on October 19, 2015, Trudeau became Canada's 23rd Prime Minister, easily trouncing the unpopular Harper government in a federal election. 
Trudeau's first few months in power were positive, not least because of his stated commitment to do politics differently, and to have greater transparency in government. The first Canadian Prime Minister to have gender equity in his cabinet, Trudeau often referred to himself as a feminist. Additionally, he promised to improve the material conditions, and government relationships, with Indigenous people by acting upon the recommendations of Canada's Truth and Reconciliation Committee. In short, Trudeau presents as a forward-thinking, responsible leader. Later, we see how Trudeau's unwillingness to listen to diverse voices, a key component of leading responsibly, starts to unravel, which brings us to our second actor.

Actor \# $\mathbf{2}$ is SNC Lavalin, the tenth largest engineering company in the world, employing 9,000 Canadians, 3,400 of them in Quebec, and a further 40,000 employees across the world. This company's business practices have been under increasing scrutiny for over a decade. In 2015, for example, SNC-Lavalin was charged with bribery and fraud, relating to its business dealings in Libya during the Gadhafi regime (Paikan, 2018). However, this is not the first corruption charge for this company, and SNC has been banned from bidding on World Bank contracts (Fyfe, 2019). SNC has also been accused of bribing top level administrators at a hospital in Montreal, a case currently before the courts.

With regard to the Libyan accusation, SNC-Lavalin hoped to avoid criminal charges through a deferred prosecution agreement (DPA). A DPA is sometimes be used by public prosecutors when a corporation agrees it has committed a crime. In brief, the company agrees to pay back profits, as long as the prosecutor drops criminal charges. This legislation was originally used in the United States following the financial crash of 2008, when many corporations and their senior executives were allowed to pay fines, rather than face bribery and corruption charges in court. SNC-Lavalin lobbied the Trudeau government, as well as opposition leaders, to get 
similar legislation introduced in Canada. The legislation was introduced in summer 2018; however, SNC's lobbying efforts have not been altogether successful, due, in part, to the actions of our next player.

Actor \#3 is Jody Wilson-Raybould, Canada's former Justice Minister and Attorney General, is a member of the We Wai Kai nation and from British Columbia. Encouraged by Trudeau to enter politics, she had a meteoric political rise. In 2014, Wilson-Raybould was elected to parliament and, in November 2015, became Canada's first Indigenous Justice Minister, an appointment welcomed by First Nations groups across the nation. In January 2019, however, Wilson-Raybould was transferred to Veterans Affairs, widely seen as a demotion. And, on Feb 12, 2019, The Globe and Mail reported that Wilson-Raybould had been pressured by the Prime Minister's Office to help SNC-Lavalin obtain a DPA. Shortly after this story broke, Ms. Wilson-Raybould resigned. When asked by reporters for his reaction to her resignation, Trudeau initially expressed surprise. His initial surprise turned to apparent frustration in later media interviews, following her startling testimony to the federal Standing Committee on Justice and Human Rights.

At this Committee, Wilson-Raybould testified that the Prime Minister's Office had pressured her to secure a DPA for SNC-Lavalin. She told the Committee that, in a meeting with the Prime Minister and the Privy Council Secretary, in fall 2018, she was informed that, without a deferred prosecution agreement, many jobs would be lost. Wilson-Raybould told the Prime Minister that she would not interfere with the decision, already made by the Public Prosecutor. At which point, according to her account, Trudeau stated there was an upcoming election in Quebec, and said "I am an MP in Quebec.” In response, Wilson-Raybould asked the Prime Minister whether he was trying to direct her, which she strongly urged against, since it would be 
read as political interference with the judicial process. Wilson-Raybould further testified that, although it would have been appropriate to discuss job losses prior to her making a decision, after the decision had been made, any political interference was inappropriate. Yet people in the Prime Minister's Office kept asking her to change the decision, which brings us to our final player.

Actor \# 4 is Gerald Butts. Widely seen as the mastermind of Trudeau's rise to power, Butts served as the Prime Minister's Principal Secretary from November 2015 until February 2019, when he resigned from his role, due to the escalating media scandal over the SNC-Lavalin affair. Butts' resignation was all the more confusing because he argued that neither he nor his staff had acted inappropriately, thus contradicting Wilson-Raybould's comments.

The week following Wilson-Raybould's testimony, Butts testified before the same federal Committee. He told the Committee that he took full responsibility for the breakdown in trust between the Prime Minister's Office and the Attorney General. Butts also testified that noone had asked Wilson-Raybould to change her decision, and that he was fully aware that this decision rested with the Attorney General. But since the PMO never received a written notification about her decision, he and his staff continued to make entreaties to WilsonRaybould. These entreaties included asking her to obtain a second opinion. A second opinion was warranted, Butts said, because the loss of 9,000 jobs was a public policy matter, which could have potential repercussions for many Canadian workers and their families.

A few days after Butts' testimony, Trudeau spoke to the press. In concert with Butts, he said there had been a breakdown in trust between the Attorney General and the PMO. Trudeau also told the press that he had been listening and learning from this event. Then he repeated Butts' claim that no-one in the Prime Minister's Office had acted inappropriately. Like Butts, 
Trudeau maintained that there was no undue pressure placed on Wilson-Raybould, and that he was in full support of the actions taken by the staff in the PMO's office. Trudeau also agreed with Butts that the loss of 9.000 jobs was a political issue, although this number of potential job losses has been disputed not only by the media, but also by the CEO of SNC-Lavalin (Marowits, 2019). Further, when asked by reporters whether he would apologize to the Canadian people, Trudeau deflected the question by stating that he was about to apologize to the Inuit people on behalf of past government actions. In short, while Trudeau was willing to take collective responsibility for the mistakes of past governments, he was unwilling to take personal responsibility for this particular crisis.

\section{Discussion and conclusion - No more Mr. Nice Guy}

What are we to make of this case, and what insights does it offer on leading responsibly, and its connections with judgment? First, SNC-Lavalin has shown itself to be irresponsible in its dealings, both at home and abroad. Second, Trudeau's actions in encouraging the former Attorney General to intervene in this legal case appear irresponsible. Indeed, the opposition parties accuse him of potential criminal negligence, a matter currently under investigation by the Ethics Commissioner. Third, Butts is seen to have taken the blame for this fiasco, even though he continues to protest there was no wrong-doing. And what of Ms. Wilson-Raybould's responsibility not only as the Attorney General, but also as Minister of Justice, a member of cabinet? Politically, her action may appear irresponsible, as several Liberal MPs argued. Rather than showing loyalty, Wilson-Raybould's action has created a scandal. This scandal may prove devastating not only to Trudeau's reputation, but also to the Liberals' chance of re-election later this year. 
This political scandal led to another Ministerial resignation by Jane Philpott, as well as on-going calls by the opposition of a cover-up. A further problem for Trudeau is that WilsonRaybould and Philpott refused to remain silent, speaking out about this affair both within parliament, and to the media. Their outspokenness led to them being ousted from the Liberal caucus. In response, in a speech to the First Nations of Canada, Philpott (2018) argued that the SNC-Lavalin debacle represented a "serious clash of cultures." While "in theory there is a desire for diversity in politics," she said, "in reality, it seems Ottawa is not entirely ready for people who approach leadership and responsibility from different worldviews." Is this a clash of worldviews, as Philpott maintains, or an instance when a leader's political responsibility and individual judgment diverge?

One problem arising from this political scandal is the difficulties that emerge when communication falters. Wilson-Raybould testified that, instead of having conversations with the Prime Minister on this matter, most of her interactions happened with others, thus increasing the likelihood of miscommunication. When dialogue between key players breaks down, this can negatively affect the ability to judge and act in a responsible manner. Furthermore, a lack of dialogue can, as in this instance, lead to a breach of trust between individuals. Such a breakdown in communication can also have a profound effect on a leader's ability to assess what the best course of action might be. Rather than a leadership moment, which Ladkin (2010) describes as an instance where context, leader, follower, and purpose align, this example suggests the opposite. Indeed, what this case reveals is the problems that occur when a leader privileges one set of responsibilities over another. The fact that SNC-Lavalin is based in Quebec is not without relevance here. To win another majority government, Trudeau and his party must hold on to seats in Quebec. The Prime Minister has a responsibility, as he sees it, to save jobs. On the other, 
Trudeau has a larger responsibility, that of keeping himself and his party in power. Looking at this political scandal from different sides we see just how complex the role of political leader is, and how important it is to not only act responsibly, but in a manner that others view as responsible and just.

In this instance, it appears we have an apparent failure on the part of a leader to think through this problem from different standpoints, critical not only to an Arendtian idea of judgment, but also to the stakeholder premise of responsible leadership (Maak \& Pless, 2006; Gardiner, 2018). Furthermore, it highlights Ladkin's (2010) assertion that it is critical that leaders take the time to reflect upon decisions, after weighing up different options. In this case, listening carefully to all stakeholders, a key aspect of responsible leadership, does not seem to have occurred.

In my opinion, Trudeau appears to care deeply about Canada and the Canadian people. But in his rush to keep jobs in Quebec, Trudeau has sullied his reputation. On this occasion, we see a Prime Minister acting irresponsibly, not just in the manner in which he dealt with this issue at the time, but in his subsequent comments to the media where he refused to apologize for his action. If Wilson-Raybould's account is correct, then rather than listening to diverse stakeholders and taking a more measured response to the possible closure of SNC-Lavalin in Canada, Trudeau failed to do the necessary thinking that would allow him to judge appropriately, and act in a responsible way.

For her part, Wilson-Raybould has shown Canadians that there are different approaches to leadership. For example, in her testimony, she stated: "I come from a long line of matriarchs and I am a truth teller in accordance with the laws and traditions of our Big House - this is who I am and who I will always be." Her statement suggests that judging for ourselves is vital to 
ensuring we remain true to our principles. And yet, in politics, there may be problems with appealing to truth for, as Arendt (1992) contends, "the modes of thought and communication that deal with truth if seen from the political perspective, are necessarily domineering” (p. 107). To speak one's truth might appear to contradict the agonistic back and forth of political dialogue that Arendt regards as fundamental to the political realm. In Arendtian terms, it is because the political must be a space of plurality - a space where diverse opinions are encouraged to emerge that a singular truth can never be privileged. But that is not to say that truth does not matter in politics, but rather that diverse opinions are needed to make this space meaningful. Yet although the truth teller may not make a regular appearance in political life, they are needed, Arendt (1993) informs us, whenever organized lying infiltrates a political community. As she states "[w]here everybody lies about everything of importance, the truth teller, whether he knows it or not, has begun to act" (p. 251). That action is vital to the long-term health of the political realm, even though the truth teller may be penalized for speaking out.

The more I reflect on this case, what becomes apparent is that whenever dialogue breaks down, so, too, does the ability to judge and act in a responsible way. And when dialogue between leader and others breaks down so, too, does trust, as is evident in this case. Arendt (1992) tells us that "[j]udgement may require us to make the effort to understand those whose point of view we do not share by may even find distasteful" (p. 100). In this case, the players concerned are all adamant they did nothing wrong, which is unlikely. Some Canadians tell me this issue is not important, given the political malfeasance that we see elsewhere. Perhaps they are right. Yet Arendt tells us to be wary about minor transgressions on the part of our political leaders. These minor transgressions can lead to greater wrongdoings. 
Trudeau positioned himself as a different kind of leader. He promised that his government would be responsible and transparent - promises he failed to keep in this instance. Even if his motives were genuine, Trudeau showed a lack of responsibility in allowing his staff to interfere with the judicial process, as well as a blinkered view of his responsibilities.

One wonders why Trudeau would give up political and moral capital to promote the interests of a particular corporation. I find his action difficult to fathom, especially given this corporation had previously been accused of unethical behaviour. Of course, a cynic might argue Trudeau's action was aimed at currying favor in one part of the country, Quebec, since, without the support of Quebecers, the Liberals cannot win another majority government. Cynicism aside, I am reminded of Arendt's (1965) comments regarding the problem when a leader's desire to do good deeds, in this case, Trudeau's standing up for Canadian jobs, which in theory is a good thing for a leader to do, obscures his ability to judge fully the effects of his action. Doing what a leader think is good is not always a wise move. Arendt (2003b) maintains, following Machiavelli, that it "is not whether the individual is good but whether his conduct is good for the world he lives in" (p. 151). She was fond of quoting Machiavelli's advice to rulers, such as that, in politics, "care for the world" always trumps the care of the self (p. 50). The problem when political leaders try to "do good" is that it can lead to cries of hypocrisy, as this political scandal demonstrates. Instead of a leader being true to their values, what is more important is that a leader's actions are good for the world.

One reason this scandal gained so much traction is because Trudeau promised he would do politics differently. When politicians campaign on doing politics in a transparent manner, citizens may resent feeling their trust was misplaced. Furthermore, this scandal has been exacerbated by Trudeau's unwillingness to take responsibility for his actions. Arendt (1958) tells 
us that promising to do what we say is an important facet of being responsible. So is showing contrition for errors in judgment. Such contrition demonstrates our humility, and our willingness to face up to mistakes. But, in this case, humility is far from evident.

Trudeau came into politics, promising Canadians that we could return to "sunny ways." After a decade of right-wing government, this promise was one many Canadians found enticing. But four years on, those promises have been eclipsed by this political scandal. In Trudeau's (2014) autobiography, he notes how "much of politics is fleeting and ephemeral" (p. 224). What matters, he argues, is the "hope and trust" people invest in you (p. 225). But when citizens put their hope and trust in a leader, any perceived wrongdoing is likely to be met with dismay, and even anger, as Trudeau's ratings in recent polls demonstrate (Kalvapalle, 2019). Will the Prime Minister be forgiven by the Canadian public? Their forgiveness, or lack thereof, will be made known when Canadians go to the polls later this year.

Finally, Arendt encourages us to recognize that acting responsibly is, above all, a judgment call. Such a judgment call is rarely easy, especially for the political leader who has so many decisions to make. That said, it is important for leaders not only to take responsibility for their actions, but also to engage in the critical thinking that Arendt regards as fundamental to good judgment. This requires leaders to listen carefully to dissenters, as well as assenters. The question that remains: do our leaders care enough about the world to engage in the kind of critical reflection that Arendt argues is vital for judging the most responsible course of action? 


\section{References}

Arendt, H. (1958). The Human Condition. Chicago: University of Chicago Press.

Arendt, H. (1963). Eichmann in Jerusalem: A report on the banality of evil. London \& New York: Penguin books.

Arendt, H. (1965). On Revolution. New York: Viking books.

Arendt, H. (1978). The Life of the Mind. Edited by Mary McCarthy. New York: Harcourt, Brace and Jonavich.

Arendt, H. (1992). Lectures on Kant's Political Philosophy. Edited, preface and interpretive essay by Ronald Beiner. Chicago: University of Chicago Press.

Arendt, H. (1993). “Truth and Politics.” In Between Past and Future, pp. 227-265. London and New York: Penguin.

Arendt, H. (2003a). "Personal responsibility under dictatorship" In Responsibility and Judgment, edited by Jerome Kohn, pp. 17-48, New York: Schocken Books.

Arendt, H. (2003b). “Collective Responsibility,” In Responsibility and Judgment, edited by Jerome Kohn, pp. 147-159, New York: Schocken Books.

Benhabib, S. Ed. (2010). Politics in dark times: Encounters with Hannah Arendt. Cambridge: Cambridge University Press.

Borren, M. (2010). Amor mundi: Hannah Arendt's political phenomenology of the world. Unpublished dissertation. Accessed June 28, 2019. https://dare.uva.nl/search?identifier=3e10dd75-e8c8-46c3-a3cb-b2e4997c6177

Diprose, R. (2008). Arendt and Nietzsche on responsibility and futurity. Philosophy \& Social Criticism, 34(6): 617-642. 
Gardiner, R. (2018). Ethical responsibility - An Arendtian turn. Business Ethics Quarterly, 28(1): 31-50.

Gardiner, R. (2015). Gender, authenticity and leadership: Thinking with Arendt. London \& New York: Palgrave MacMillan.

Harris, K. (March, 2019). https://www.cbc.ca/news/politics/butts-snc-lavalin-wilson-raybould1.5044704. Accessed March 6, 2019.

Kalvapalle, R. (March, 28, 2019). Trudeau now has a lower approval rating than Trump, with Tories way ahead. Accessed April 26, 2018. https://globalnews.ca/news/5103763/trudeauapproval-rating-snc-lavalin-budget/

Ladkin, D. (2010). Rethinking leadership. Cheltenham, UK: Edward Elgar.

Maak, T. \& Pless, N. (2006). "Responsible Leadership in a Stakeholder Society: A Relational Perspective," Journal of Business Ethics, 66, (1), 99-115.

Marowits, R. (2019). SNC never mentioned 9,000 job losses, CEO says. Global News. Accessed July 16, 2019. https://globalnews.ca/news/5077066/snc-lavalin-ceo-job-losses/

Mrovlje, M. (2019). Rethinking political judgment: Arendt and existentialism. Edinburgh University Press.

Paikin, S. (Feb 19, 2019). Corporations and corruption in Canada: Fraud, bribery, and scandal. https://www.youtube.com/watch?v=8r6SUm3m3UA. Accessed February, 26, 2019.

Smith, M. D. (March, 12, 2019). OECD announces it is monitoring SNC-Lavalin scandal, raising prospect Canada has violated international anti-bribery agreement. National Post. https://nationalpost.com/news/politics/oecd-announces-it-is-monitoring-snc-lavalin$\underline{\text { scandal-raising-prospect-canada-has-violated-international-anti-bribery-agreement }}$ Accessed March 12, 2019. 
Trudeau, J. (2014). Common Ground. New York: HarperCollins Publisher.

Vasterling, V. (2010). Cognitive theory and phenomenology in Arendt's and Nussbaum's work. Human Studies, 30, 75-99.

Young-Bruehl, E. (1992). Hannah Arendt: For love of the world. New Haven and London: Yale University Press.

Zimonjic, P. (Feb, 2019). Jody Wilson-Raybould: A timeline in federal politics. https://www.cbc.ca/news/politics/jody-wilson-raybould-timeline-1.5016755. Accessed February 20, 2019. 